Genij Ortopedii. 2021. Vol. 27, no. 5. P. 548-554.

Original article

https://doi.org/10.18019/1028-4427-2021-27-5-548-554

\title{
The choice of a spacer at the first stage of treatment for late deep periprosthetic hip joint infection
}

\section{S.A. Linnik ${ }^{1}$, G.E. Afinogenov ${ }^{2}$, A.G. Afinogenova ${ }^{2,3}$, G.E. Kvinikadze', D.V. Kravtsov ${ }^{1}$, N.M. Klushin ${ }^{4}$, D.Yu. Maday ${ }^{2}$, V.M. Khaidarov ${ }^{1}$, G. Karagezov ${ }^{1}$, A.A. Vorokov ${ }^{1}$}

\author{
${ }^{1}$ North-Western State Medical University named after I.I. Mechnikov, Saint Petersburg, Russian Federation \\ ${ }^{2}$ Saint Petersburg State University, St. Petersburg, Russian Federation \\ ${ }^{3}$ Saint-Petersburg Pasteur Institute, St. Petersburg, Russian Federation \\ ${ }^{4}$ Ilizarov National Medical Research Centre for Traumatology and Orthopedics, Kurgan, Russian Federation \\ Corresponding author: Dmitry V. Kravtsov, Dmitrii.Kravtcov@szgmu.ru
}

\begin{abstract}
Introduction Periprosthetic infection in hip arthroplasty is a social and economic problem. Its main reason is multidrug resistance of microorganisms. Purpose To evaluate the effectiveness of the first stage in two-stage revision arthroplasty for the treatment of deep periprosthetic infection of the hip joint by improving the constructive and antibacterial features of spacers. Materials and methods The treatment results of 127 patients with late deep periprosthetic hip joint infection who underwent two-stage revision arthroplasty in the period from 2015 to 2019 were analyzed. In the first group, 42 patients were fitted with a two-component (total) spacer based on the developed antimicrobial composition of bone cement with gentamicin, antiseptics and polymer (patent RU191236). In the second group, a two-component spacer (patent RU174697) based on conventional bone cement with gentamicin was implanted in 43 patients; the third group of 42 patients had a preformed spacer. Results A bactericidal and antiadhesive, non-toxic composition based on bone cement with gentamicin with antiseptics poviargol, dioxidine and high molecular weight polyvinylpyrrolidone with a prolonged action for 348 days against gentamicin-resistant staphylococci has been developed. All patients underwent the first stage of hip arthroplasty with removal of the implant and installation of a spacer. Recurrence of periprosthetic infection was observed in 1 (2.3\%) patient of the first group, in $5(11.6 \%)$ in the second and in $6(14.2 \%)$ patients of the third group. Non-infectious complications such as spacer dislocation and instability were observed in 12 cases, one case $(2.3 \%)$ in the first, $2(4.6 \%)$ in the second and $9(21.4 \%)$ in the third group. The average time from the first stage of treatment to the second stage of re-implantation was 7.5 months (range, 4-13 months). Discussion According to the literature, the introduction of new antibiotics into the bone cement with gentamicin does not increase the antimicrobial action of the spacer, especially against antibiotic-resistant isolates, and the use of a preformed spacer contributes to an increase in the number of non-infectious complications. Antiseptics with different mechanisms of action are able to act on antibiotic-resistant bacteria, and the polymer can prolong this effect. Conclusions Creation of two-component spacers based on bone cement with gentamicin using antiseptics with different mechanisms of action and polymer promotes long-term bactericidal action of the spacer, which leads to effective sanation of the joint area, reducing non-infectious complications.
\end{abstract}

Keywords: hip joint, periprosthetic infection, spacer, antimicrobial composition, two-stage revision endoprosthesis replacement

For citation: Linnik S.A., Afinogenov G.E., Afinogenova A.G., Kvinikadze G.E., Kravtsov D.V., Klushin N.M., Maday D.Yu., Khaidarov V.M., Karagezov G. Vorokov A.A. The choice of a spacer at the first stage of treatment for late deep periprosthetic hip joint infection. Genij Ortopedii, 2021, vol. 27, no 5, pp. 548-554. https://doi.org/10.18019/1028-4427-2021-27-5-548-554

\section{INTRODUCTION}

According to many authors, total hip arthroplasty (THA) is one of the most common operations that restore joint function and improve the patient's quality of life [1-6]. However, various complications of this operation may reach $16.6 \%[5,6]$, of which the most severe and costly are infectious ones. Periprosthetic joint infection (PJI) may from 0.3 to $3 \%[4,7,9,10]$, and after revision intervention for PJI it may reach $6.2 \%[1,3,8,10]$. According to the Australian registry for 2018, the $\mathrm{PJI}$ is $18.1 \%$ and ranks fourth in terms of the frequency of repeated interventions, and according to the Swedish register for 2017, the PPI ranks first [11].

The main causes of recurrent PJI are pathogenic gram-positive and gram-negative microorganisms or their associations, including multi-resistant to various antimicrobial drugs, methicillin- and gentamicin-resistant staphylococci. Antibioticresistant bacteria, being causative agents of PJI, decrease the effectiveness of the sanitizing stage of revision arthroplasty and etiotropic antibiotic therapy and often cause the recurrence [12-15]. The adhesion of bacteria to the implant may run various mechanisms, for instance, through direct nonspecific interaction between the pathogen and the artificial surface of the "host" due to physicochemical factors (electrostatic field, surface tension, van der Waals forces, hydrophobicity and hydrogen bonds). There is evidence that the adhesion of microbes to the implant is selective, depending on the material from which it is made. Thus, colonization by Staphylococcus epidermidis strains frequently occurs on the polymer parts of the endoprosthesis while by $S$. aureus strains on its metal parts $[16,17]$.

The main method of PJI treatment is two-stage revision arthroplasty. The first stage is the debridement and sanitizing of the purulent focus and the second is actual prosthesis implantation [2, 8, 10, 18, 19]. Frequent relapses of the purulent process and noninfectious complications after the sanitizing stage of the revision are associated with an insufficient and short-term antibacterial effect [20, 21], design

(c) Linnik S.A., Afinogenov G.E., Afinogenova A.G., Kvinikadze G.E., Kravtsov D.V., Klushin N.M., Maday D.Yu., Khaidarov V.M., Karagezov G., Vorokov A.A., 2021 
of spacers and the lack of choice of tactics for their use depending on the type of bone defects in the hip joint. Further study and solution of this problems is a significant issue.
Purpose To evaluate the effectiveness of the first stage of treatment of deep periprosthetic hip joint infection in two-stage revision arthroplasty by improving the design and antibacterial features of the spacers used.

\section{MATERIAL AND METHODS}

Treatment of 127 patients aged 45 to 73 years with hip PJI, who underwent the sanitizing stage of revision arthroplasty in the period from 2015 to 2019 were analyzed. Among them 71 (55.9\%) were males and $56(44.1 \%)$ females. Inclusion criteria were deep periprosthetic hip infection that developed after primary and revision arthroplasty. Exclusion criteria were sepsis and severe physical condition at the time of admission to the hospital.

The first group consisted of 42 patients who received a two-component (total) spacer based on an antimicrobial composition of prolonged action. The second group included 43 patients who had a twocomponent spacer that was composed of regular bone cement with gentamicin, and the third group consisted of 42 patients who received a preformed spacer.

Standard bone cement with gentamicin, antiseptics poviargol [metallic silver nanoclusters stabilized with low molecular weight polyvinylpyrrolidone (PVP)] and dioxidine [a derivative of hydroxyquinoline], a synthetic polymer of high molecular weight polyvinylpyrrolidone, were used to develop and study the antimicrobial composition. Evaluation of the bactericidal activity of the composition was carried out by standard microbiological methods (diffusion into agar and quantitative plate-suspension). Toxicity analysis was carried out in vivo on experimental animals and in vitro on a culture model of fibroblast cells of human embryonic skin; the antiadhesive effect of the composition was additionally studied.

The study was approved by the local ethics committee; it was conducted in accordance with the ethical standards set out in the 1975 Declaration of Helsinki, revised in 2008.

Prior to admission to the clinic, 50 (39.4\%) patients underwent primary hip arthroplasty due to coxarthrosis, $43(33.8 \%)$ aseptic necrosis of the femoral head, 18 $(14.2 \%)$ dysplastic coxarthrosis, fracture of the femoral neck were $11(8.7 \%)$ cases and 5 patients $(3.9 \%)$ were after revision arthroplasty. PJI term from the stage of primary arthroplasty ranged from 2.5 to 11 months (average, $6.5 \pm 4.7$ months); terms of hospitalization in the clinic upon the diagnosis of PJI ranged from 3.1 to 7.2 months (average, $5.2 \pm 2.6$ months).

Instability of the implant components was observed in $10(23.8 \%)$ patients of the first group, $12(27.9 \%)$ patients of the second and $10(23.8 \%)$ patients in the third group. The study included patients with acetabular defects I, IIA, IIB, IIC types according to W.G. Paprosky [22] and types I, II femoral defects according to the classification of T.H. Mallory (1988) [23] modified by W.G. Paprosky (1994) [22]. The choice of a spacer depending on the type of defect according to the W.G. Paprosky and T.H. Mallory did not differ significantly in the compared groups of patients $(p>0.05)$. The clinical manifestations in patients with PJI were characterized by symptoms of inflammation (fever) and sinuses. The majority of patients (more than $90 \%$ ) complained of pain, dysfunction of the hip joint.

All patients were assessed for joint function and quality of life using the Harris Hip Score, WOMAS and VAS scales before performing the first and second stages of revision THA. Hematological studies (leukocytosis, LII, ESR and CRP) were performed before and after the first sanitizing stage of the operation.

The decisive confirmation of the PJI of the hip is bacteriological examination. For this, before performing the first stage, at least 3 times with an interval of 3-4 weeks, diagnostic punctures of the joint cavity were performed. Bacteriological contents of the sinuses were cultured. However, the results of the biomaterial from the sinuses do not always reflect the true picture of the microbial presence. Occasionally, late periprosthetic infection can be caused by normal skin microflora (S. epidermidis).

To identify additional cavities, infected hematomas, abscesses communicating with the joint cavity, and to obtain more reliable data all patients underwent sonographic examination of the hip joint area before puncture. These studies were carried out before the first stage of revision and in 12 patients with recurrent PJI after the debridement stage.

In addition to hematological and bacteriological studies, radiological diagnostic methods were used. Plain radiography was taken in all patients. It revealed the instability of the implant components, destruction and the nature of bone defects. In the presence of sinuses that were present in 18 patients of the first, 17 second and 20 third groups, fistulography was performed. Computed tomography was used in 38 patients $(12,14$ and 12 patients from three groups, respectively) to detect instability of the implant components and osteolysis.

All patients with late deep PJI in the area of hip joint, confirmed by the data of clinical, laboratory (hematological), bacteriological and radiological research methods, underwent the first sanitizing stage of revision and also a course of parenteral combined etiotropic antibiotic therapy for at least 10 days according to the results of preoperative and intraoperative bacteriological study, and then oral administration for 6-8 weeks. After discontinuation of antibiotics, 1214 days later, joint puncture was performed three times with an interval of 3-4 weeks under ultrasound control to detect dormant infection.

The first sanitizing stage of revision included removal of implant components, bone cement, other foreign bodies, pathologically altered tissues, and at least 5 biopsy samples were taken from the surgical wound for microflora and to determine sensitivity to 
antibiotics. The wound was thoroughly washed using pulse lavage. According to the size of the medullary canal and the acetabulum, a preformed (according to radiographs) spacer on cement was installed or a twocomponent spacer was prepared. The pelvic component of the spacer was made in the following way.

Patients of the first group: bone cement powder with gentamicin, poviargol, dioxidine, PVP was placed in a sterile mortar and a liquid plasticizer was added. Patients of the second group: only bone cement with gentamicin and a plasticizer were added and mixed with a sterile spatula. The resulting plastic mass was poured into a special mold for the pelvic component with the outer diameter corresponding to the size of the acetabulum and the inner diameter corresponding to head diameter, $28 \mathrm{~mm}$ or $32 \mathrm{~mm}$. The polymerization time in the first group averaged $14.8(13.7-15.8)$ minutes, in the second group it was 10.5 (10.1-11.5) minutes. In the first group, the pelvic component of the spacer was installed on cement, which includes the antimicrobial composition proposed, and in the second group on cement with gentamicin. At the beginning and at the end of the operation (intraoperatively), intravenous antibiotic therapy was performed according to the antibiocogram data based on the results of preliminary bacteriological cultures of punctates taken before the operation.

Statistical processing of the obtained data was performed using the STATISTICA10 for Windows. To assess the statistical significance of differences in mean values in the groups, we used Student's t-test, Fisher's test, $\chi^{2}$. Differences in indicators between groups were considered significant at $\mathrm{p}<0.05$.

\section{RESULTS}

The data of the analysis of the treatment outcomes of patients, depending on the type of spacer used, has enabled to assess the effectiveness of the products. Commonly used spacers have a short antibacterial effect and imperfect technical performance resulting in $\mathrm{PJI}$ recurrence and non-infectious complications.

To reduce the percentage of complications such as spacer dislocation, protrusion into the pelvic cavity, as well as to increase the duration of the antimicrobial effect of its surface, we have developed a two-component spacer, which contains the proposed antimicrobial composition. The spacer consists of a pelvic component formed during surgery, a metal head and a stem. To prevent head dislocation, a visor was formed in the pelvic component of the spacer (utility model patent RU174697) (Fig. 1). Cement fixation of the pelvic component of the spacer avoids the formation of debris, friction between the spacer and the acetabulum and, as a consequence, its protrusion into the pelvic cavity before the second stage of revision. The average bed-day term after the sanitizing stage in the first group was $18 \pm 2.6$ days, in the second group $-23 \pm 8.7$ days, and $31 \pm 6.2$ days in the third group. The increased bed-day term in patients of the second and third groups is associated with the treatment of complications in the postoperative period, which were more common in patients of these groups.

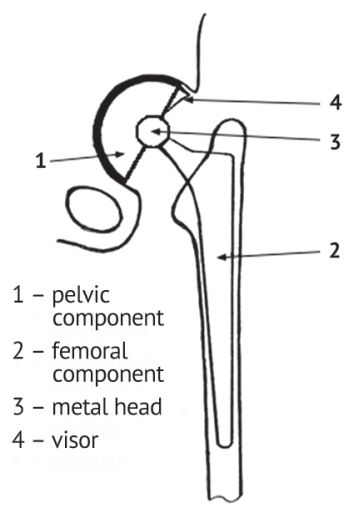

Fig. 1 Two-piece hip joint space

We have developed an antimicrobial composition based on standard bone cement with gentamicin supplemented by antiseptics with different mechanisms of action (poviargol and dioxidine), as well as a polymer of high molecular weight polyvinylpyrrolidone. Such ingredients provide a prolonged antimicrobial effect and a detoxifying effect of the mixture. Data on the assessment of toxicity (in vitro and in vivo) and anti-adhesive activity of the mixed composition on the culture of human embryonic fibroblasts indicate that the developed composition is safe and prevents the adhesion of pathogenic microorganisms. The results obtained in vitro confirm the presence of the bactericidal effect of the extracts from the composition against gentamicin-resistant and gentamicin-sensitive strains of S. epidermidis for 348 days (patent for invention RU191236) [16]. On the contrary, an increase in the population of the test strain S. epidermidis was noted after 3 weeks on the surface of the control spacer made of bone cement with gentamicin, while no growth of the microorganism was observed on the test samples of the spacer supplemented with the developed composition, which indicates the ability of antiseptics to prevent the formation of microbial biofilms on the surface of the implant. Thus, the proposed composition, which includes the approved for use in the clinic poviargol, dioxidine antiseptics with a broad spectrum of bactericidal action and high molecular weight PVP, as a component of detoxification and prolongation of the antimicrobial effect, are non-toxic, have a prolonged antimicrobial and antiadhesive effect.

Before the first sanitizing stage of revision, the proportion of detected gram-positive pathogens in the first group of patients was $67.9 \%$, and in the second and third groups $70.1 \%$ and $69.2 \%$, respectively. Gram-negative microflora (Pseudomonas spp., Acinetobacter spp., Klebsiella spp., Citrobacter spp.) was found in $13.7 \%$ of cases in the first group, in $16.5 \%$ and $16.7 \%$ of cases in the second and third groups, respectively. S. aureus and S. epidermidis were found most frequently, including methicillin-resistant isolates that were about $30 \%$. Microbial associations were obtained in $18.4 \%$ of cases in the first group, in $13.4 \%$ of cases in the second and $14.1 \%$ in the third group.

Analysis of hematological parameters of patients before the first stage of revision showed an increase in 
the normal values in all groups (Table 1). At the same time, there were no statistically significant differences in hematological parameters $(\mathrm{p}>0.05)$ among the patients of the compared groups. After the first sanitizing stage in the first group, where a spacer with an antimicrobial composition was used, the leukocytosis index, ESR and CRP values were normalized after 21 days, while in the second and third groups these indicators remained elevated, especially in the third group, where a preformed spacer was used, which could indicate the possibility of PJI recurrence.

In total, infection recurred in $12(9.4 \%)$ patients, of which $1(2.3 \%)$ in the first group, which is significantly $(p<0.05)$ less often than in the patients of the second group: 5 (11.2 \%). When comparing the number of PJI relapses in patients of the first ( 1 case, $2.3 \%$ ) and third (6 cases, $14.2 \%$ ) groups, there is also a statistically significant relationship, but between the second and third groups, the difference is insignificant.

A comparative analysis of the microflora in 12 patients with recurrent PJI before, during the operation and 1-1.5 months after the relapse showed the coincidence of the pathogens detected in 9 patients, and in the remaining three cases, other types of microorganisms such as gram-negative bacteria joined the initial pathogens in 1 patient, methicillin-resistant staphylococcus in 2 patients.
Most of the non-infectious complications (Table 2) in the cases of a preformed spacer were associated with its monoblock shape, a small number of standard sizes, what does not always provide optimal joint relationships in accordance with the sizes of the implant head and acetabulum. Moreover, when the limb moves in the hip joint, friction occurs between the cement head of the spacer and the bottom of the acetabulum, increasing pain and sometimes leading to its protrusion into the pelvic cavity.

Prior to the sanitizing stage of PJI treatment, the unsatisfactory result was $29.0 \pm 5.2$ (24-34) HHS points [24], and before the second stage, $60.4 \pm 5.4$ points (54 63). The severity of pain on the VAS scale [25] before sanitizing stage was $8(6-10)$, and before the second stage of revision was $3(2-4)$; on the WOMAS scale [26] 66 and 42, respectively. The presented data indicate an improvement in the function of the hip joint in 117 patients before the second stage of revision arthroplasty. Evaluation of the quality of treatment results after the second (final) stage, depending on the use of various spacers at the first stage, may be the subject of further research, taking into account the revision systems used, the nature of surgical interventions and the state of bone tissue.

The majority of reoperations before the second stage of revision were performed in the third (15), almost 2 times less in the second (7), and only 2 in the first group (Table 3 ).

Table 1

Hematological parameters before and after the sanitizing stage of the revision operation

\begin{tabular}{|c|c|c|c|c|c|c|c|c|c|}
\hline \multirow{2}{*}{ Groups } & \multirow{2}{*}{ Parameter } & \multicolumn{8}{|c|}{ Observation term } \\
\hline & & \multicolumn{2}{|c|}{ Before the operation* } & \multicolumn{2}{|c|}{$7^{\text {th }}$ post-op day } & \multicolumn{2}{|c|}{$14^{\text {th }}$ post-op day } & \multicolumn{2}{|c|}{$21^{\text {st }}$ post-op day $* *$} \\
\hline \multirow{4}{*}{$\begin{array}{c}1 \\
(\mathrm{n}=42)\end{array}$} & Leukocytosis, $10^{9} / 1$ & \multicolumn{2}{|c|}{$10.5(6.4-11.2) \pm 0.17$} & \multicolumn{2}{|c|}{$8.3(7.1-9.2) \pm 0.07$} & \multicolumn{2}{|c|}{$6.4(5.8-7.7) \pm 0.07$} & \multicolumn{2}{|c|}{$6.2(5.4-6.8) \pm 0.05$} \\
\hline & LII, $\mathrm{mm} / \mathrm{h}$ & \multicolumn{2}{|c|}{$1.6(1.4-3.3) \pm 0.07$} & \multicolumn{2}{|c|}{$1.2(0.6-1.4) \pm 0.03$} & \multicolumn{2}{|c|}{$1.2(0.6-1.4) \pm 0.03$} & \multicolumn{2}{|c|}{$1.0(0.5-0.9) \pm 0.01$} \\
\hline & ESR, $\mathrm{mm} / \mathrm{h}$ & \multicolumn{2}{|c|}{$30.2(25.5-40.2) \pm 0.52$} & \multicolumn{2}{|c|}{$22.0(17.2-21.7) \pm 0.16$} & \multicolumn{2}{|c|}{$12.5(10.7-15.6) \pm 0.17$} & \multicolumn{2}{|c|}{$10.2(8.7-12.1) \pm 0.12$} \\
\hline & CRP, mg / 1 & \multicolumn{2}{|c|}{$16.8(14.2-25.4) \pm 0.40$} & \multicolumn{2}{|c|}{$14.8(11.3-19.2) \pm 0.28$} & \multicolumn{2}{|c|}{$13.1(9.8-14.4) \pm 0.16$} & \multicolumn{2}{|c|}{$4.7(3.7-9.6) \pm 0.28$} \\
\hline \multirow{4}{*}{$\begin{array}{c}2 \\
(\mathrm{n}=43)\end{array}$} & Leukocytosis, $10^{9} / 1$ & \multicolumn{2}{|c|}{$10.7(8.1-14.6) \pm 0.23$} & \multicolumn{2}{|c|}{$10.1(7.9-12.4) \pm 0.16$} & \multicolumn{2}{|c|}{$9.8(8.1-11.2) \pm 0.11$} & \multicolumn{2}{|c|}{$9.1(7.7-10.9) \pm 0.21$} \\
\hline & LII, $\mathrm{mm} / \mathrm{h}$ & \multicolumn{2}{|c|}{$2.4(0.9-2.7) \pm 0.06$} & \multicolumn{2}{|c|}{$1.8(1.6-2.1) \pm 0.02$} & \multicolumn{2}{|c|}{$1.5(1.3-1.8) \pm 0.02$} & \multicolumn{2}{|c|}{$1.5(0.8-1.7) \pm 0.03$} \\
\hline & ESR, $\mathrm{mm} / \mathrm{h}$ & $30.7(22$. & $.2) \pm 0.64$ & $22.9(20$ & 7.4) \pm 0.25 & $18.1(15$ & .7) \pm 0.32 & $15.4(10$ & 1) \pm 0.24 \\
\hline & CRP, mg / 1 & $22.7(15$. & 7.9) \pm 0.42 & $16.4(12$ & $3.8) \pm 0.38$ & $16.2(12$ & $11) \pm 0.45$ & $8.7(6$ & \pm 0.41 \\
\hline & Leukocytosis, $10^{9} / 1$ & $12.1(9.3$ & 7) \pm 0.12 & $11.0(9$. & $.0) \pm 0.21$ & $10.2(9$. & $0) \pm 0.10$ & 9.9( & \pm 0.13 \\
\hline & LII, $\mathrm{mm} / \mathrm{h}$ & $2.5(1$ & \pm 0.06 & 1.9( & \pm 0.05 & 1.6( & 0.04 & 1.5 & $=0.02$ \\
\hline$(n=42)$ & ESR, mm / hour & $31.5(22$. & $.1) \pm 0.70$ & $23.1(19$ & t.3) \pm 0.17 & $19.2(16$ & $8) \pm 0.31$ & $16.2(1$ & 9) \pm 0.22 \\
\hline & $\mathrm{CRP}, \mathrm{mg} / \mathrm{l}$ & $23.1(17$. & $.7) \pm 0.37$ & 17.7 & t.4) \pm 0.32 & $17.0(13$ & .9) \pm 0.35 & $9.3(7.2$ & \pm 0.44 \\
\hline$* *$ & differences in in & rs betw & ps of patie & $\begin{array}{l}\text { ients b } \\
\text { e 21st }\end{array}$ & $\begin{array}{l}\text { ery are no } \\
\text { servation a }\end{array}$ & t sign & 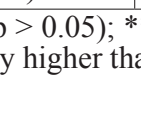 & - th & ces in the \\
\hline & & & ct & to & th & he & & & Table \\
\hline & & & & & & & & & \\
\hline Complica & ation & Grou & $=42)$ & Grou & =43) & Groul & $=42)$ & ota & 127) \\
\hline & & $\mathrm{n}$ & $\%$ & $\mathrm{n}$ & $\%$ & $\mathrm{n}$ & $\%$ & $\mathrm{n}$ & $\%$ \\
\hline Spacer di & islocation & 0 & 0 & -2 & 2.3 & 5 & 11.9 & 6 & 4.7 \\
\hline Spacer in & nstability & 1 & 2.4 & 1 & 2.3 & 2 & 4.8 & 4 & 3.2 \\
\hline Protrusio & in into pelvic cavity & 0 & 0 & 0 & 0 & 2 & 4.8 & 2 & 1.6 \\
\hline Total & & 1 & 2.4 & 2 & 4.6 & 9 & 21.5 & 12 & 9.5 \\
\hline
\end{tabular}


Table 3

Types of interventions after sanitizing stage of revision

\begin{tabular}{|c|c|c|c|c|c|c|c|c|}
\hline \multirow{3}{*}{ Type of intervention } & \multicolumn{6}{|c|}{ Group of patients } & \multirow{2}{*}{\multicolumn{2}{|c|}{ Total }} \\
\hline & \multicolumn{2}{|c|}{ Group 1} & \multicolumn{2}{|c|}{ Group 2} & \multicolumn{2}{|c|}{ Group 3} & & \\
\hline & $\mathrm{n}$ & $\%$ & $\mathrm{n}$ & $\%$ & $\mathrm{n}$ & $\%$ & $\mathrm{n}$ & $\%$ \\
\hline Repeated debridement, change of spacer & 1 & 4.2 & 5 & 20.8 & 6 & 25.0 & 12 & 50.0 \\
\hline Change of spacer & 1 & 4.2 & 1 & 4.2 & 8 & 33.2 & 10 & 41.6 \\
\hline Open reduction of spacer & 0 & 0 & 1 & 4.2 & 1 & 4.2 & 2 & 8.4 \\
\hline Total & 2 & 8.4 & 7 & 29.2 & 15 & 62.4 & 24 & 100 \\
\hline
\end{tabular}

After the repeated debridement operation and changing the spacer with a two-component one with the developed antimicrobial composition, it was possible to achieve elimination of PJI in 1 patient in each of the second and third groups. Thus, elimination of the focus of infection and stable remission was achieved in 41 $(97.6 \%)$ patients of the first group, in $39(90.7 \%)$ in the second and in $37(88.1 \%)$ patients in the third group. Reinstallation of the spacer due to its instability and dislocation was carried out more often in patients of the third group $-9(\mathrm{p}<0.05)$, compared with the first (1) and second (2) groups.

After at least three negative results of microbiological cultures from the joint 2-3 weeks after the termination of antibiotic therapy, 117 (92.1\%) patients underwent the second stage of revision arthroplasty using revision systems. PJI recurred in $10(7.9 \%)$ patients $(1 / 4 / 5$, respectively the groups). Of these, in two patients, further surgical tactics of treatment were not applied. One patient with severe concomitant pathology, along with treatment aimed at eliminating the purulent process, underwent complex detoxification, restorative, antibacterial and immunostimulating therapy. Another patient with satisfactory joint function, a supportable limb and a stable spacer, the presence of a fistula with scanty discharge, refused further surgical treatment. Eight (6.3\%) patients underwent implant removal and revision arthroplasty after unsuccessful (up to 3 times) sanitizing operations.

\section{DISCUSSION}

Two-stage revision arthroplasty is the method of choice for late deep PJI. According to the literature, the success of two-stage revision in the treatment of PJI ranges from 60 to $90 \%[4,7,27]$. Re-infection process after the first sanitizing stage of re-implantation occurs in $7.9-24.7 \%$ of cases and in 14.6-28\% after the second stage [7, 28, 29]. Despite the achieved success in the treatment of PJI, recurrence remains a significant burden. A decrease in the effectiveness of PJI treatment is associated with the participation in the etiology of the disease of an implant-associated infection caused by a conditionally pathogenic human microflora such as epidermal staphylococcus, multi-resistant strains of microorganisms and the increasing role of their associations [13, 29, 30].

The results of our study show that infection was eliminated in the overwhelming (88.1-97.6\%) number of patients after the sanitizing stage of PJI hip joint treatment, depending on the tactics of the treatment used.

To enhance the effectiveness of the first stage of revision, N.S. Nikolaev et al., K.L. Romano et al. used the implants coated with various preparations that prevent the formation of microbial biofilms [31-33]. The authors achieved significantly better PJI treatment outcomes using silver-ligated 2D-linear-chain carboncoated implants. It was shown that this method reduces the level of synovial fluid cytosis before the second revision stage. Various technologies of antibacterial coating of implants for arthroplasty have proven to be safe and effective, enabling to reduce the incidence of infectious complications by 80-90\% and significantly decrease economic costs [31-33].
To improve the outcomes of PJI treatment, prolong the antimicrobial action of the used spacers and prevent recurrence of PJI S.A. Bozhkova et al. proposed to use dioxidine to enhance the action of gentamicin, which enhances the bactericidal effect of bone cement against methicillin-resistant strains of staphylococci, and also to use a mixture of polyvinylpyrrolidone, gentamicin and dioxidin for interoperative wound irrigation [34]. However, such methods have a short term of antimicrobial action.

The antimicrobial composition proposed by us for the formation of a spacer based on bone cement with gentamicin, containing antiseptics and a polymer with a detoxifying effect, achieves a prolonged antimicrobial effect in the joint area for 348 days, including against antibiotic-resistant isolates.

Unfortunately, the literature lacks data on noninfectious complications after the first stage of revision arthropasty for PJI. Those might be dislocation of the spacer, its instability, fracture of metal structures, protrusion of the acetabulum [35, 36]. Thus, V.Yu. Murylev et al. [4] indicate that mechanical (noninfectious) complications after the sanitizing stage of the operation with the installation of a spacer may reach $21 \%$, of which spacer dislocation is $10.4 \%$, fracture of the metal structure and spacer is $5.2 \%$, protrusion into the pelvic cavity is $5.2 \%$. J. Jung et al. [35] described the incidence of mechanical complications in $40.8 \%$ of cases (17\% of dislocations, $10.2 \%$ of spacer breaks, $3.6 \%$ of femur fractures). To prevent these complications, it is necessary to carefully plan the sanitizing stage of revision and to consider the defects in the bone tissue of the acetabulum and femur according to W.G. Paprosky [22]. 
Our study is devoted to improving the outcomes of the first stage of a two-stage revision arthroplasty by developing a prolonged-acting antimicrobial composition for creating spacers and improving their design features. The use of the developed technologies allowed us to reduce the number of relapses of the infectious process in the first group of patients, who received a spacer from the proposed antimicrobial composition, in comparison with the second and third groups. The use of the developed two-component spacers, taking into account the types of bone defects in the hip joint, contributed to a decrease in the number of non-infectious complications in comparison with the use of a preformed spacer.

\section{CONCLUSION}

Creation of two-component spacers based the spacer, including against antibiotic-resistant on bone cement with gentamicin and antiseptics microorganisms. It ensures effective sanation of with different mechanisms of action and polymer the joint area and optimization of the timing of the contributes to the long-term bactericidal action of second stage of re-implantation.

\section{REFERENCES}

1. Zagorodnii N.V., Nuzhdin V.I., Kagramanov S.V., Khoranov Iu.G., Kudinov O.A., Aiushev D.B., Kuzmin F.A, Buravtsova M.E., Chragian G.A., Bukhtin K.M., Erokhin P.A., Nikolaev I.A. 20-letnii opyt endoprotezirovaniia krupnykh sustavov v spetsializirovannom otdelenii TsITO im N.N. Priorova [20-year experience of large joint arthroplasty in Priorov CITO specialized department]. Vestnik Travmatologii i Ortopedii im. N.N. Priorova, 2011, no. 2, pp. 52-58. (in Russian)

2. Tikhilov R.M., Shubniakov I.I., editors. Guide to hip surgery. Vol. 1. SPb., Vreden RNIITO, 2014, 368 p. (in Russian)

3. Minasov B.Sh., Iakupov R.R., Khairov T.E., Gafarov I.R., Sirodzhov K.Kh., Karimov K.K., Filimonov G.N., Trubin A.R. Artroplastika tazobedrennogo sustava posle reduktsionno-rekonstruktivnykh vmeshatelstv na proksimalnom otdele bedra [The hip arthroplasty after reduction-and-reconstruction interventions of proximal femur]. Genij Ortopedii, 2015, no. 4, pp. 21-26. (in Russian)

4. Murylev V.Iu., Kukovenko G.A., Elizarov P.M., Ivanenko L.R., Sorokina G.L., Rukin Ia.A., Alekseev S.S., Germanov V.G. Algoritm pervogo etapa lecheniia pozdnei glubokoi periproteznoi infektsii tazobedrennogo sustava [Algorithm of the first stage of treating late deep periprosthetic infection of the hip]. Travmatologiia i Ortopediia Rossii, 2018, vol. 24, no. 4, pp. 95-104. (in Russian) DOI: 10.21823/2311-2905-2018-24-4-95-104.

5. Parvizi J., Tan T.L., Goswami K., Higuera C., Della Valle C., Chen A.F., Shohat N. The 2018 Definition of Periprosthetic Hip and Knee Infection: An evidence-based and validated criteria. J. Arthroplasty, 2018, vol. 33, no. 5, pp. 1309-1314.e2. DOI: 10.1016/j.arth.2018.02.078.

6. Goel R., Tarabichi M., Azboy I., Kheir M.M., Parvizi J. Management of periprosthetic joint infection. Minerva Ortop. Traumatol., 2017, vol. 68, no. 4, pp. 207-215. DOI: 10.23736/S0394-3410.17.03842-5.

7. Pavlov V.V., Petrova N.V., Sheraliev T.U. Srednesrochnye rezultaty dvukhetapnogo lecheniia periproteznoi infektsii [Mid-term results of two-stage treatment of periprosthetic infection]. Travmatologiia i Ortopediia Rossii, 2019, vol. 25, no. 4, pp. 109-118. (in Russian) DOI: 10.21823/2311-2905-201925-4-109-116.

8. Shubniakov I.I., Tikhilov R.M., Denisov A.O., Akhmedilov M.A., Chernyi A.Zh., Totoev Z.A., Dzhavadov A.A., Karpukhin A.S., Muraveva Iu.V. Chto izmenilos v strukture revizionnogo endoprotezirovaniia tazobedrennogo sustava v poslednie gody? [What has changed in the structure of revision hip arthroplasty in recent years?]. Travmatologiia i Ortopediia Rossii, 2019, vol. 25, no. 4, pp. 9-27. (in Russian) DOI: 10.21823/2311-2905-2019-25-4-9-27.

9. Linnik S.A., Kvinikadze G.E., Kravtsov D.V., Afinogenov G.E., Afinogenova A.G., Spiridonova A.A., Kucheev I.O., Romashov P.P., Sabaev D.A. Obosnovanie vybora speisera pri lechenii pozdnei periproteznoi infektsii oblasti tazobedrennogo sustava [Rationale for the choice of a spacer in the treatment of late periprosthetic infection of the hip joint]. Profilakticheskaia i Klinicheskaia Meditsina, 2019, no. 3 (72), pp. 79-85. (in Russian)

10. Ermakov A.M., Kliushin N.M., Ababkov Iu.V., Triapichnikov A.S., Koiushkov A.N. Otsenka effektivnosti dvukhetapnogo khirurgicheskogo lecheniia bolnykh s periproteznoi infektsiei kolennogo i tazobedrennogo sustavov [Efficiency of two-stage revision arthroplasty in management of periprosthetic knee and hip joint infection]. Genij Oropedii, 2018, vol. 24, no. 3, pp. 321-326. DOI: 10.18019/1028-4427-2018-24-3-321-326.

11. Kukovenko G.A., Elizarov P.M., Alekseev S.S., Sorokina G.L., Ivanenko L.R., Erokhin N.E., Muzychenkov A.V., Murylev V.Iu. Vazhnost vypolneniia algoritma diagnostiki pozdnei glubokoi periproteznoi infektsii tazobedrennogo sustava [The importance of performing the algorithm for diagnosing late deep periprosthetic hip infection of the hip]. Travmatologiia i Ortopediia Rossii, 2019, vol. 25, no. 4, pp. 75-87. (in Russian) DOI: 10.21823/2311-29052019-25-4-75-87.

12. Bozhkova S.A., Bogdanova T.Ia., Krasnova M.V., Anisimova L.O., Netylko G.I., Rukina A.N., Liu B. Eksperimentalno-klinicheskoe issledovanie fenotipicheskikh osobennostei shtammov S. Epidermidis i ikh rol v vozniknovenii i razvitii implantat-assotsiirovannoi infektsii posle ortopedicheskikh operatsii [Experimental-and-clinical investigation of the phenotypic characteristics of S. Epidermidis strains and their role in the emergence and development of implant-associated infection after orthopedic surgeries]. Travmatologiia i Ortopediia Rossii, 2014, no. 2, pp. 68-77. (in Russian)

13. Liventsov V.N., Bozhkova S.A., Kochish A.Iu., Artiukh V.A., Razorenov V.L., Labutin D.V. Trudnoizlechimaia periproteznaia infektsiia tazobedrennogo sustava: rezultaty saniruiushchikh operatsii [Intractable periprosthetic hip infection: results of sanitizing operations]. Travmatologiia $i$ Ortopediia Rossii, 2019, vol. 25, no. 4, pp. 88-97. (in Russian) DOI: 10.21823/2311-2905-2019-25-4-88-97.

14. Papadopoulos A., Ribera A., Mavrogenis A.F., Rodriguez-Pardo D., Bonnet E., Salles M.J., Dolores Del Toro M., Nguyen S., Blanco-García A., Skaliczki G., Soriano A., Benito N., Petersdorf S., Pasticci M.B., Tattevin P., Tufan Z.K., Chan M., O'Connell N., Pantazis N., Kyprianou A., Pigrau C., Megaloikonomos P.D., Senneville E., Ariza J., Papagelopoulos P.J., Giannitsioti E.; ESCMID Study Group for Implant-Associated Infections (ESGIAI). Multidrug-resistant and extensively drug-resistant Gram-negative prosthetic joint infections: Role of surgery and impact of colistin administration. Int. J. Antimicrob. Agents, 2019, vol. 53, no. 3, pp. 294-301. DOI: 10.1016/j.ijantimicag.2018.10.018.

15. Fagotti L., Tatka J., Salles M.J.C., Queiroz M.C. Risk Factors and Treatment Options for Failure of a Two-Stage Exchange. Curr. Rev. Musculoskelet. Med., 2018, vol. 11, no. 3, pp. 420-427. DOI: 10.1007/s12178-018-9504-1.

16. Afinogenova A.G., Kvinikadze G.E., Spiridonova A.A., Afinogenov G.E., Linnik S.A., Madai D.Iu. Mikrobiologicheskoe obosnovanie sozdaniia kompozitsii na osnove kostnogo tsementa s prolongirovannym antimikrobnym deistviem v otnoshenii gentamitsin-ustoichivykh Staphylococcus Epidermidis [Microbiological substantiation of the creation of a composition based on bone cement with a prolonged antimicrobial action against gentamicin-resistant Staphylococcus Epidermidis]. Problemy Meditsinskoi Mikologii, 2018, vol. 20, no. 4, pp. 49-54. (in Russian)

17. Kilmetov T.A., Akhtyamov I.F., Galmutdinov I.Sh., Gatina E.B., Eremin I.K., Aliev E.I-A., Ismailov Kh.G-O. Lokalnaia antibiotikoterapiia pri infektsii oblasti endoproteza sustava [Local antibiotic therapy in case of infection of the joint implant region]. Kazanskii Meditsinskii Zhurnal, 2014, vol. 95, no. 3, pp. 405-411. (in Russian)

18. Prokhorenko V.M., Pavlov V.V. Infectious complications of hip arthroplasty. Novosibirsk, Nauka, 2010, 179 p. (in Russian)

19. Triapichnikov A.S., Ermakov A.M., Kliushin N.M., Ababkov Iu.V., Stepanian A.B., Koiushkov A.N. Rezultaty lecheniia periproteznoi infektsii krupnykh sustavov u VICH-pozitivnykh bolnykh [Results of treatment of periprosthetic infection of large joints in HIV-positive patients]. Travmatologiia $i$ Ortopediia Rossii, 2019, vol. 25, no. 4, pp. 117-125. (in Russian) DOI: 10.21823/2311-2905-2019-25-4-117-125.

20. Mendel V., Simanowski H.J., Scholz H.C., Heymann H. Therapy with gentamicin-PMMA beads, gentamicin-collagen sponge, and cefazolin for experimental osteomyelitis due to Staphylococcus aureus in rats. Arch. Orthop. Trauma Surg., 2005, vol. 125, no. 6, pp. 363-368. DOI: 10.1007/s00402-004-0774-2.

21. Gatina E.B., Mitronin M.I., Akhtyamov I.F., Ziatdinov B.G., Kilmetov T.A., Eremin I.K. Infektsionnye oslozhneniia kak pokazateli smeny variantov 
lecheniia v travmatologii i ortopedii [Infectious complications as indicators of a change in treatment options in traumatology and orthopedics]. Prakticheskaia Meditsina, 2013, vol. 2, no. 1-2, pp. 34-36. (in Russian)

22. Paprosky W.G., Bradford M.S, Younger T.I. Classification of bone defects in failed prostheses. Chir. Organi Mov., 1994 , vol. 79, no. 4, pp. 285-291.

23. Mallory T.H. Preparation of the proximal femur in cementless total hip revision. Clin. Orthop. Relat. Res., 1988, no. 235, pp. 47-60.

24. Mahomed N.N., Arndt D.C., McGrory B.J., Harris W.H. The Harris hip score: comparison of patient self-report with surgeon assessment. J. Arthroplasty, 2001, vol. 16, no. 5, pp. 575-580. DOI: 10.1054/arth.2001.23716.

25. Menshchikova I.A., Kolesnikov S.V., Novikova O.S. Otsenka bolevogo sindroma i stepeni vyrazhennosti koksartroza po razlichnym shkalam i testam [Assessment of the pain syndrome and coxarthrosis manifestation degree using different scales and tests]. Genij Ortopedii, 2012, no. 1, pp. 30-33. (in Russian)

26. Bellamy N., Buchanan W.W., Goldsmith C.H., Campbell J., Stitt L.W. Validation study of WOMAC: a health status instrument for measuring clinically important patient relevant outcomes to antirheumatic drug therapy in patients with osteoarthritis of the hip or knee. J. Rheumatol., 1988, vol. 15, no. 12, pp. 1833-1840.

27. Komarov R.N., Mitrofanov V.N., Novikov A.V., Korolev S.B. Taktika lecheniia infektsionnykh oslozhnenii posle endoprotezirovaniia tazobedrennogo sustava.Travmatologiia i Ortopediia Rossii, 2016, vol. 22b, no. 4, pp. 25-34. (in Russian) DOI: 10.21823/2311-2905-2016-22-4-25-34.

28. Lange J., Troelsen A., Søballe K. Chronic periprosthetic hip joint infection. A retrospective, observational study on the treatment strategy and prognosis in 130 non-selected patients. PLoS One, 2016, vol. 11, no. 9, pp. e0163457. DOI: 10.1371/journal.pone.0163457.

29. Vinkler T., Trampush A., Rents N., Perka K., Bozhkova S.A. Klassifikatsiia i algoritm diagnostiki i lecheniia periproteznoi infektsii tazobedrennogo sustava [Classification and algorithm of diagnosis and treatment of the hip periprosthetic infection]. Travmatologiia i Ortopediia Rossii, 2016, no. 1, pp. 33-45. (in Russian) DOI: 10.21823/2311-2905-2016-0-1-33-45.

30. Zmistowski B., Fedorka C.J., Sheehan E., Deirmengian G., Austin M.S., Parvizi J. Prosthetic joint infection caused by gram-negative organisms. J. Arthroplasty, 2011, vol. 26, no. 6 Suppl., pp. 104-108. DOI: 10.1016/j.arth.2011.03.044.

31. Nikolaev N.S., Liubimova L.V., Pchelova N.N., Preobrazhenskaia E.V., Alekseeva A.V. Ispolzovanie implantatov s pokrytiem na osnove dvumernouporiadochennogo lineino-tsepochechnogo ugleroda, legirovannogo serebrom, dlia lecheniia periproteznoi infektsii [Use of implants coated on the basis of 2D-ordered linear-chain carbon, doped with silver, for periprosthetic infection treatment]. Travmatologiia i Ortopediia Rossii, 2019, vol. 25, no. 4, pp. 98108. (in Russian) DOI: 10.21823/2311-2905-2019-25-4-98-108.

32. Tapalskii D.V., Nikolaev N.S., Ovsiankin A.V., Kochakov V.D., Golovina E.A., Matveenkov M.V., Sukhorukova M.V., Kozlov R.S. Pokrytiia na osnove dvumerno uporiadochennogo lineino-tsepochechnogo ugleroda dlia zashchity titanovykh implantatov ot mikrobnoi kolonizatsii [Coatings based on twodimensionally ordered linear-chain carbon to protect titanium implants from microbial colonization]. Travmatologiia i Ortopediia Rossii, 2019, vol. 25, no. 2, pp. 111-120. (in Russian) DOI: 10.21823/2311-2905-2019-25-2-111-120.

33. Romano K.L., Bozhkova S.A., Artiukh V., Tsuchiia Kh., Drago L. Primenenie implantatov s antibakterialnym pokrytiem v ortopedii i travmatologii: sovremennoe sostoianie problemy [Using the implants with antibacterial coating in orthopedics and traumatology: current state of the problem]. Travmatologiia i Ortopediia Rossii, 2019, vol. 25, no. 4, pp. 64-74. (in Russian) DOI: 10.21823/2311-2905-2019-25-4-64-74.

34. Bozhkova S.A., Kasimova A.R., Tikhilov R.M., Poliakova E.M., Rukina A.N., Shabanova V.V., Liventsov V.N. Neblagopriiatnye tendentsii v etiologii ortopedicheskoi infektsii: rezultaty 6-letnego monitoringa struktury i rezistentnosti vedushchikh vozbuditelei [Adverse trends in the etiology of orthopedic infection: results of 6-year monitoring of the structure and resistance of the leading pathogens]. Travmatologiia i Ortopediia Rossii, 2018, vol. 24, no. 4, pp. 20-31. (in Russian)

35. Jung J., Schmid N.V., Kelm J., Schmitt E., Anagnostakos K. Complications after spacer implantation in the treatment of hip joint infections. Int. J. Med. Sci., 2009, vol. 6, no. 5, pp. 265-273. DOI: 10.7150/ijms.6.265.

36. Faschingbauer M., Reichel H., Bieger R., Kappe T. Mechanical complications with one hundred and thirty eight (antibiotic-laden) cement spacers in the treatment of periprosthetic infection after total hip arthroplasty. Int. Orthop., 2015, vol. 39, no. 5, pp. 989-994. DOI: 10.1007/s00264-014-2636-z.

37. Linnik S.A., Kvinikadze G.E., Kucheev I.O., Russu I.I., Radysh V.G., Aliev N.S. Speiser tazobedrennogo sustava [The hip spacer]. Patent RF no. 174697, A 61 B 17/56, A 61 F 2/32, 2017. (in Russian)

38. Linnik S.A., Kvinikadze G.E., Afinogenova A.G., Afinogenov G.E., Madai D.Iu., Trofimova M.A., Berdes A.I., Iachmenev A.N., Serdobintsev M.S., Deliev B.I. Speiser tazobedrennogo sustava [The hip spacer]. Patent RF no. 191236, A 61 B 17/56, 2019. (in Russian)

39. Afinogenova A.G., Afinogenov G.E., Linnik S.A., Kvinikadze G.E., Spiridonova A.A., Madai D.Iu., Cherkasov A.Iu. Antimikrobnaia kompozitsiia dlia formirovaniia speisera [Antimicrobial composition for spacer formation]. Patent RF no. 2707734, A 61 K 31/7036 A 61 F 2/28 A 61 L 27/54 A 61 P 31/00, 2019. (in Russian)

The article was submitted 05.10.2020; approved after reviewing 20.04.2021; accepted for publication 23.08.2021.

\section{Information about the authors:}

1. Stanislav A. Linnik - Doctor of Medical Sciences, Professor, stanislavlinnik@mail.ru;

2. Gennady E. Afinogenov - Doctor of Medical Sciences, Professor, gennady-afinogenov@yandex.ru;

3. Anna G. Afinogenova - Doctor of Biological Sciences, spbtestcenter@mail.ru;

4. Guram E. Kvinikadze - M.D., guram88@inbox.ru;

5. Dmitry V. Kravtsov - Candidate of Medical Sciences, Dmitrii.Kravtcov@szgmu.ru;

6. Nikolai M. Kliushin - Doctor of Medical Sciences, klyushin_nikolay@mail.ru;

7. Dmitry Yu. Maday - Doctor of Medical Sciences, wpxmdy@mail.ru;

8. Valeriy M. Khaidarov - Candidate of Medical Sciences, Valerii.Khaidarov@szgmu.ru;

9. Giorgi Karagezov - M.D., giorgikaragezov@gmail.com;

10. Alimbek A. Vorokov - M.D., Alimbek.Vorokov@szgmu.ru.

Conflict of interest No conflict of interest declared. 